\title{
THE HATE PROPAGANDA AMENDMENTS: REFLECTIONS ON A CONTROVERSY
}

\author{
MAXWELL COHEN*
}

The recent hate propaganda amendments to the Criminal Code were subjected to a stormy journey through Parliament, from introduction in 1966, to final passage in June of this year.

Professor Cohen, having chaired the Special Committee on Hate Propaganda, gives an informative account of the history of the problem, the debate surrounding it, and how the inescapable conclusion was reached that the law was sorrowfully lacking in its treatment of the most important aspects of the hate propaganda problem.

The controversial debate over the amendments to the Criminal Code to control "Hate Propaganda" ended with its passage by Parliament in June of 1970.1 Few pieces of legislation in recent years have evoked or provoked such strong divisions of opinion, not only on the part of those who might be expected to support or oppose such legislation but, more significantly perhaps, among those who held in common their devotion to free speech in particular and civil liberties in general. That the latter should be strongly divided on grounds of both principle and legal technique makes it necessary to assess the nature of the controversy, the results hoped for in the legislation, and perhaps more important, the place of such controls within a relatively free society at a time when there are new threats to both freedom and "order". Indeed, it is the general social context of growing anxieties about the conflicting pressures to protect freedom, and yet to find new ways of controlling disorder - which themselves may or may not threaten basic freedoms-that undoubtedly contributed to escalating the controversy, perhaps beyond what might have been the case in less troubled times.

The general history of the legislation has recently been summarized with considerable objectivity in a useful paper entitled "The Story Behind Canada's New Anti-Hate Law" by Mr. B. G. Kayfetz." No purpose would be served therefore in a detailed recounting of that story. Nevertheless, for a proper evaluation of the legislation it is necessary to examine at least the following:

1. What gave rise to the demand that such legislation be enacted?

2. What were the means used by the Government of Canada to determine the need for legislation and the scope of possible amendments to the Criminal Code?

3. How did Parliament approach the problem of deciding upon the legislation as it was finally enacted?

4. Does the legislation, in the overall, serve a constructive democratic purpose and what are the unknowns which all civil libertarians may conscientiously be concerned about now that the legislation has been enacted?

- Macdonald Professor of Law. McGill University, and sometime Chairman of the Minister of Justice Special Committee on Hate Propaganda, 1965-66. The views are those of the writer only and not of the Committee.

I Actual passage in the Senate was completed in May but Royal Assent was not given until June 11. 1970.

- Kayfetz. The Story Behind Canada's New Anti-Hate Law, (1970) Patterns of Prejudice at 5-8. 


\section{A. WHAT GAVE RISE TO THE DEMAND THAT SUCH LEGISLATION BE ENACTED?}

As Kayfetz points out, requests for legislation against religious and racial hate propaganda go back at least to March 1953, when representations were made by interested and classically "vulnerable" minority groups to a Joint Committee of the House of Commons and Senate dealing with revisions of the Criminal Code.: But the origins of anxiety in this area are a good deal older than this formal demarche. Indeed, as long ago as 1933-34 when Nazi-type propaganda began to make its appearance in various parts of Canada, Manitoba enacted a statute attempting to deal with the issue.' That legislation remains on the books of that Province to the present day-whatever the questions raised about its constitutionality.

The post-war years left in Canada and among all the anti-Hitler allies some continuing sensitivity to the Nazi-Fascist program, philosophy and political tactics aimed at the incitement to contempt and hatred certainly by Germans, and of others as well, toward particular "target groups". Indeed, racial theories of superiority on the one side, and of conspiracy and "inferiority" on the other were dominant features of Nazi ideology and were given the sanction and "prestige" of law both in Germany and often also in the areas occupied by the Third Reich and its allies."

It may be said, therefore, that the "free world" emerged from World War II-apart from the special physical immunities of North Americascarred not only by the general effects of a global war of immense proportions, but also scarred in a psychological sense by the introduction into the political and military conflict of a deep ideological division, one of whose principal elements were race theories expressed in a variety of forms but most conspicuously and tragically in its denigration of many vulnerable minority groups through providing for their virtual "outlawry" by specific legislation denying them not merely "rights" but the elementary right of existence itself."

While the anti-semitic component, of this period of heightened race propaganda in Germany and elsewhere, may have been its most dramatic and publicized form of expression, these concepts, ideas and laws were by no means confined to anti-Jewish policies. In any event, the total effect was to create a tradition within the Third Reich, and the occupied areas, of open and official "hatred" toward particular groups on grounds of race, religion, nationality, or ethnic origin generally-to which, of course, should be added a parallel political and legal philosophy that was anti-liberal, anti-freedom, "anti-socialist", as an overall objective of repressing anti-fascism and compelling conformity to the "new order".

It was not without significance therefore that by the middle of the 1950's a number of the West European countries occupied by Hitler's Germany had enacted legislation forbidding varieties of hate propaganda directing an animus towards groups on racial, religious, ethnic or similar grounds.' Indeed, the Charter of the United Nations also

I Id., at 5-6.

+ S.M. 1934 c. 23; R.S.M. 1954, c. 185.

- Shirer, The Rise and Fall of the Third Reich (1960) at 231-236.

" Report of the Special Commitee on Hate Propaganda (1966) at 24-25; Appendix II, 121.

: Report, supra, n. 6 at 277-288. 
reflected this broad determination to reject racism and advance individual and group human rights through the language of its Preamble and elsewhere-all buttressed later, of course, by the Universal Declaration of Human Rights of 1948, and by subsequent Conventions in this general field. ${ }^{8}$

Nevertheless, it was clear to many observers in the post-war years that "patterns of prejudice", some of them long part of the Western tradition, had been partly reinforced by the indirect results of prolonged German propaganda. Indeed, despite the massive defeat of Hitler and of Germany there was a spill-over into the post-war period that was noticeable in the persistence with which certain types of racial propaganda, inciting hatred toward "target groups", and even advocating genocide for some, had become a reappearing phenomenon in otherwise democratic societies.

This spill-over also affected Canada throughout this period and became quite acute in the late 1950's and early 1960's with the emergence of a number of extreme right-wing groups, some natively Canadian, and others recruited from a limited number of new immigrants, and all echoing in literature or public statements views not dissimilar from the established Nazi approach toward Jews, Negroes, some Roman Catholics, and other minority targets. ${ }^{\circ}$

Thus, it was not unexpected that the quite substantial distribution of hate propaganda materials between 1959 and 1966, in a variety of Canadian centres, notably in Ontario and Quebec, should give rise to strong reactions on the part of the target groups concerned. This was particularly so in the case of those who were members of such groups, often new Canadians who had experienced in Europe some of the warnings and final horrors that such propaganda had represented in their own personal histories. It was inevitable, therefore, that the anxieties created by the distribution of such materials through the mails and by hand; the making of public statements by speakers in open forums; and the often clandestine character of the new organizations (small in number though they may have been) devoted to such activity; all should prompt a vigorous response on the part of those who were now Canadian "targets" whether as established Canadians or new Canadians.

The principal difficulty with the growing Canadian debate over this issue in the late 1950's and early 1960's was two-fold. On the one hand, there was a new emphasis on individual freedom now general expressed through the international symbolism of "human rights" and domestic legislation dealing with non-discrimination which seemed to emphasize increasing "rights" for the individual, his political and social opportunities for liberty of expression as well as other freedoms. On the other side, there was a growing recognition that these very liberties could be dangerously abused through their use in attacking the sense of well-being and group security, through such propaganda, and thereby threaten the goodwill and cohesion within a democratic society itself. Canadians were made increasingly aware of this issue also by the depth and danger of the evolving Quebec and French-English problem and the challenges to the federal system itself. Moreover, the substantial number of studies emerging from research in the field of social psycho-

4 Arts. 1, 55, 56, 57; Report, supra, n. 6 at 289-303.

I Report, supra, n. 6 at 11-25. 
logy and group relations increasingly supported the view that propaganad could influence materially the attitude of many otherwise reasonable people to say nothing of its very direct effect on those already prone to extreme prejudice, and even more tragically, it affected the self-image of the target groups themselves." Finally, just as the Universal Declaration of Human Rights and all democratic legal systems recognized that liberty was not absolute if its tools and principles were employed to destroy the society itself, so there was already a public readiness to examine what balance should be drawn between freedom of expression and freedom from target exposure in a legal system and a social tradition already weighted in favour of the right to speak on, and to communicate about, almost any and all ideas as part of the democratic process itself.

\section{B. THE MEANS USED TO DETERMINE THE NEED FOR SUCH LEGISLATION}

In January of 1965 the then Minister of Justice, the Honourable Guy Favreau, appointed a Special Committee on Hate Propaganda with terms of reference to study the problems as these had crystallized in increasing demands for action from several target groups and other national organizations not so attacked." The Committee reported in November 1965 in a Report that was unanimous and which contained both specific recommendations in the form of a potential draft bill as well as other proposals not put in legislative form.": The Committee also included in its Report a number of appendices, the most important of which were a detailed study on "sedition" and on "seditious libel" and related offences in England, the United States and Canada; and a social-psychological analysis of hate propaganda in the form of a survey of the literature in the field amounting to a comprehensive overview of the post-war studies in this area. ${ }^{1: "}$ And, finally, there was a considerable amount of documentation, both national and international, dealing with existing legislation, "international" and domestic," together with a sample collection of the hate propaganda materials distributed in Canada, almost all of which were published here or imported from Sweden or the United States. "i:

Some of the debate over the Bill has centered on the value and quality of the Report, measured by the technical competence of the membership of the Committee to deal with the legal and social-psychological issues involved." It is difficult for the writer to engage in comment on this aspect, for obvious reasons. It may be a sufficient answer to say, however, that to the best of the writer's knowledge, no single critic of the Report, or the subsequent legislation, has been able to demonstrate that the technical level of the research done on the legal problems or on the social-psychological issues was less than that required by a Committee strongly aware of its need to determine for itself

In Id., at 171-250.

11 Id., at 1-3. The members of the Committee were: Dr. J. A. Corry, LABbé Gérard Dión. Mr. Saul Hayes, Q.C., Prof. Mark R. MacGuigan. Mr. Shane Mackay. Prof. Plerre Elliott Trudeau; and as Executive Assistant to the Chairman, and Secretary of the Committee, Mr. Harvey Yarosky. The autior was Chalrman.

1. Report, supra, n. 6 at 69-71.

i.: Id., at 73-251.

i. Id., at $277-303$.

i.: Id., at 253-271.

ii See particularly the views of Prof. Alan Mewett of the University of Toronto expressed on a number of occasions. 
the essential legal and psychological issues and to evaluate accordingly the status of the law in Canada and elsewhere and the status of socialpsychological knowledge concerning the nature and effects of racist propaganda and kindred matters. It was and is possible for other generalists or specialists to deny in whole or in part the conclusions arrived at by the Special Committee, namely, that existing Canadian law was inadequate to contain hate propaganda activities or that the social damage to "target groups", and the community as a whole, was not effectively demonstrated. But at least a serious reading of the Report cannot detract from the efforts made by the Committee to determine for itself whether protection was needed in this area and whether existing law afforded it. Finally, the Committee faced the difficult question of whether rules could be designed which might provide such protection with no reasonable threat to the existing Canadian traditions of free speech, in their broadest sense.

Apart from these fundamental technical-policy questions, criticism of the Report and of the proposed legislation centered also on the minimal character of the hate propaganda problem, both in the volume distributed or the number of persons and organizations involved whether as distributors or as makers of public statements in open meetings. The argument generally ran to demonstrating that very small numbers were to be considered, originally, and even less so today, as to those participating in the distribution of such propaganda or making public appearances and speeches where incitement to group hatred took place. Equally the so-called "target groups" involved were also limited in number and that these were supersensitive in a society which would have only contempt for the propaganda and that therefore such materials were, in the end. not only marginal in their impact on public opinion, but essentially irrelevant to the main stream of Canadian social debate and hence were self-defeating by the very nature of their crudity and noncredibility."

To this criticism the reply must be given that the volume of actual distribution between 1959 and 1966 in Toronto and Montreal, particularly, and in several other centres was sufficient to disturb not merely the socalled small numbers represented by the main target groups but also many organizations and persons connected with the majority groups who also felt keenly the destructive and vicious character of these materials or statements and had urged on both the Government of Canada, several of the Provinces, and upon the Special Committee itself, that measures must be found to curb and eliminate such distribution or expressions of hate propaganda."

Finally, the Committee had before it the views of the Attorney General of Canada, several of the Attorneys-General of the Provinces principally concerned, a number of leading counsel at the criminal Bar, and of the Royal Canadian Mounted Police," asserting that existing law in the Criminal Code, or elsewhere, did not provide the legal tools for the elimination of these materials or of public statements. Indeed, only in three areas did federal law appear to be effective: namely, the application, under Section 7 of the Post Office Act, of a Prohibitory

\footnotetext{
1: This view is to be found in the statements of $\mathrm{A}$ number of witnesses testifying before the Senate Committecs and in editoriai opinion critical of the proposals.

1. Report, supra, n. 6 at 59.

1:. Id., at $1-3$ and 59-60.
} 
Order which had the effect of depriving certain persons or organizations of the right to use the mails "... for the purpose of transmitting or delivering writings that are scurrilous contrary to section 153 of the Criminal Code". In due course, one such order was supported by the opinion of Wells, J. acting as a Board of Review appointed by the Postmaster General under the Post Office Act when he found that the materials dealt with in the Interim Prohibitory Order were "scurrilous" within the meaning of section 153 of the Criminal Code. ${ }^{20}$ In addition, there were the regulations under the Customs Act and the Broadcasting Act dealing in the first case with materials of a "treasonable or seditious, or of an immoral or indecent character";"' and in the second case where broadcast regulations covering radio prohibited "any abusive comment on any race or religion", and those dealing with television prohibited "any abusive comment or abusive pictorial representation on any race, religion or creed"."?

While the studies made by the Committee, and the opinions and representations presented to it, dealt in detail with many other areas of the Criminal Code and the civil law, that conceivably might be thought to apply to problems of hate propaganda, it was clear from these views and from research of the Committee itself, that the only specific and reliable protections were those referred to above, namely, section 153 of the Criminal Code, the Customs Tariff Regulations and the radio and television Regulations.

This analysis was particularly underscored by the very important changes that had taken place in the legal concept of "sedition" or "seditious libel". In its mid-nineteenth century definition, it might have covered several aspects of the problem, particularly the classical definition which included the notion of inciting or "creating ill will between one class of Her Majesty's subjects and other classes". That standard was qualified in a series of judgments culminating in Canada in the important civil liberties achievement represented by the Boucher case ${ }^{2: 3}$ which required for the effective application of the doctrine that the circumstances giving rise to the charge would have to amount to a challenge to constituted government itself.":

In view of the state of the law, as the Committee found it, and as the various law enforcement agencies, federal and provincial, declared it to be from their enforcement point of view, there was no other conclusion to which the Committee could have arrived except that existing law was inadequate, but for the above limited areas referred to.

Here, some critics have argued that no attempt was made over the years to apply many of the provisions of the Criminal Code which conceivably could have been effective to control the distribution and publication of such materials, or statements, inciting to hatred and contempt or amounting to group defamation.:": The Committee found itself unable to be persuaded, in view of the opinions and information before it, that the failure was not a failure of law but a failure of the willingness to take the forthright risks of its application. On balance,

II Id., at 42-49 and 319-327.

$\because$ Id., at 50 .

Id. at 51

:i] [1951] S.C.R. 265; |1951] 2 D.L.R. 369.

*. Rand, J. at the first hearing of Boucher v. The King |1950| 1 D.L.R. 657 at 680.

2:- These views were frequently stated in the Senate Commltee hearings and elsewhere. 
the Committee, with the views and studies available to it, could not, in all responsibility, have come to any other conclusion-namely, that the law was incomplete in its coverage of most of the more pernicious aspects of the hate propaganda problem.

The Committee concluded that there were really three main areas where the existing law simply did not supply effective answers. ${ }^{20}$ First, materials and statements "advocating" or "promoting" genocide in relation to "identifiable groups" on grounds of their religion, colour, race, language, ethnic or national origin. Secondly, materials or statements inciting "hatred" or "contempt" against any identifiable group where such incitement was likely to lead to a breach of the peace. And thirdly, materials and statements wilfully promoting hatred or contempt against any identifiable group, except where the statements communicated "were true or where if not true they were relevant to any subject of public interest, the public discussion of which was for the public benefit, and that on reasonable grounds the person charged believed them to be true".

In the Committee's view, none of these questions, as expressed by the three principle findings and recommendations listed above, were dealt with either directly or indirectly by the existing Criminal Code or could be caught by any aspects of the civil law, e.g. defamation, or non-discrimination legislation.

Given the Committee's views on the state of the law and its enforcement possibilities; given the character of the psychological effects, with their individual and social damage to target groups not merely in the eyes of the public but in the tragic self-image often created for such target groups themselves by such propaganda; and given the Committee's conviction that no freedom is absolute except perhaps the freedom to exist itself (limited perhaps only by the disappearing rules governing capital punishment); the Committee inevitably concluded that it was justified not only in making its findings but in recommending that the criminal law be altered accordingly.

Finally, the Committee took into account the important criticism aimed generally at any such controls, namely that such legislation cannot change the human heart and that fundamentally change must come from within and that the most formidable enemy of prejudice was education and not punitive criminal law. As a general proposition, the Committee accepted this broad concept of the basic role of the educational process, and of the social environment in general, as the more desirable framework within which to alter and control "patterns of prejudice". But it could not reject the double conclusion to which it came, namely that many of the community's most important self-educating values were enshrined in statements of criminal law and these in turn, once so enacted, had a continuing educational effect by their very formulation. Again the Committee also believed that the long-term process and goal of reducing or eliminating prejudice through educational and social action was not in conflict with, and could provide a necessary environment for, the more direct administrative measures required for dealing with immediate problems. Far from being mutually exclusive, the criminal law and the educational process were here complementary and 
interacting. It was for these reasons that the argument for reliance upon the educational impact on values, although fully accepted, had to be put in its proper perspective in relation to other systems of social control which themselves could have both regulatory and educational consequences. $^{2 \pi}$

\section{HOW DID PARLIAMENT APPROACH THE PROBLEM?}

The legislation has had a stormy, repetitive parliamentary history:-" Introduced first in November 1966 in the Senate where it did not reach the Committee stage, it was reintroduced the following year again in the Senate, but Parliament was prorogued in the midst of Senate Committee hearings when only two or three witnesses had been heard.

Again introduced into Senate after the 1968 Liberal election victory, with Mr. Trudeau as Prime Minister, the Senate held detailed hearings by the late winter-spring of 1969 with many witnesses and briefs before it representing a wide variety of pro and anti positions. The Bill eventually was passed by the Senate but with a number of changes from a draft that had certain awkward clauses which, while reflecting the spirit and largely the letter of the Report's recommendations, nevertheless was open to criticism on a number of technical and policy grounds, particularly the omission of "religion" among the "identifiable groups" and the power to seize hate propaganda materials independently of a trial on the merits.

But the Hearings were a quite exhaustive canvass of the policy problems even though, in this writer's opinion, the technical arguments on the major substantive provisions were unconvincing, particularly the charge that existing criminal law was sufficient: and that the Bill could or would limit free speech to a serious degree, in Canada. In substance the 1969 Hearings, as in the case of those in 1968, were alike in the concerns expressed on the one side for the defence of "target groups" against all forms of hate propaganda and, on the other, an equally powerful concern for the threat the amendments would pose to many forms of free expression in a democratic society.

Although the Bill passed the Senate in 1969, Parliament adjourned and the Bill died accordingly. But the Hearings in 1969 were chaired by that remarkable nonegarian, Senator A. W. Roebuck, who managed the proceedings with fairness and skill and the determination of an old civil libertarian himself who was convinced that such legislation was necessary. He had the support of his predecessor, the 1968 Committee Chairman Senator J. H. Prowse, who too, had given every indication of a determined sympathy for the measure and a broad understanding of its purposes, and of its possible but minimal risks.

The Bill was again introduced in the autumn of 1969 , this time as a government measure in the House of Commons where, before Second Reading, it was referred to the House Committee on Legal Affairs. Here, vigorous debate took place, with very few witnesses, but with strong advocacy by the Minister of Justice who had made already an effective and very clear address in the Commons on introducing the Bill itself. Some valuable suggestions were made in Committee which were 
adopted by the Government and the House. These were related particularly to the protection of private conversations. In the voting on the Bill in the House the Conservatives and the Creditistes were mostly against the Bill while some N.D.P. and Liberals also were opposed, but significantly a very large proportion of the House was absent on the Third Reading where the vote was 89 to 45 , with 127 not voting or absent from the Chamber.":"

In the Senate no Hearings were held, but there was determined debate and a serious but unsuccessful effort was made to have the Bill referred, before enactment, to the Supreme Court of Canada on the ground that it might be in conflict with the Canadian Bill of Rights and possibly other constitutional or statutory principles. In any event, although party lines were crossed in the voting, the Bill passed the Senate and received Royal Assent on June 11. 1970.

In general Canadian press opinion was strongly divided on the issues with probably a majority of editorialists either definitely opposed or lukewarm, but equally there were some powerful editorial voices to be heard supporting the amendments." Indeed, it may be concluded that few pieces of legislation in recent years received such a thorough and detailed examination from the point of view of principle and technique as did these Amendments.

The Bill as finally enacted, retained the three classes of offences described above, and recommended by the Report, but there were notable changes in the definition of "genocide", but retaining "promote" and "advocate": in the defences available under the group defamation provisions; in the definition of an "identifiable group"; in the role of the Attorney General of each province by permitting, with his approval only, prosecutions dealing with advocating genocide and group defamation as well as in the matter of seizure of hate propaganda materials; in removing the concept of "contempt" leaving "hatred" to stand alone in the offences concerned; and finally in the special protection given to "private conversations".

In this connection it is perhaps instructive to compare the recommendations of the Report and the Bill as enacted itself."11

\section{DOES THE LEGISLATION SERVE A CONSTRUCTIVE DEMOCRATIC PURPOSE AND WHAT ARE THE UNKNOWNS TO BE FACED?}

In this writer's view, weighted as it is in favour of the Report and its recommendations, there seems no persuasive argument in favour of permitting the advocacy of genocide; or permitting the deliberate incitement to group hatred which is likely to lead to a breach of the peace; or permitting defamation of identifiable groups, holding them up to public hatred when there are very specific safeguards leaving wide opportunities for tough debates necessary in a pluralistic, "anti-establishment" era, within a democratic society.

No purpose would be served therefore in recapitulating here the issues or the debate about them already summarized above. The signifi-

:! Id., at 7 .

iv Id., at 6-7.

:1 Report, supra, n. 6 at 69-71: Bill C-3. as passed by the House of Commons on 13 April. 1970, and accepted in that form by the Senate and given Royal Assent on June 11. 1970. 
cant question to be asked, however, is whether the amendments will achieve their preventive and deterrent objectives, and above all, whether these more refined standards for the legitimate scope of public utterances and published materials will not themselves have an educational impact in the long run more important than the immediate punitive aspects of the criminal law as such?

In this writer's opinion, the legislation provides abundant protection both in the definition of the offences, and in the permission required from the Attorneys General in several instances, to render unlikely either harassing prosecutions or easy convictions. The weight, indeed, seems to be on the other side, namely, that the legislation is so seriously concerned to protect freedom from any serious limitations that it may prove very difficult to obtain prosecutions or convictions-except in the case of "advocating genocide". Even here the offence is limited to "advocacy" and "promotion", and the definition of "genocide" has been narrowed to a degree that makes it far less comprehensive than that originally to be found in the Genocide Convention itself-which Canada now has ratified. It is obvious that the advocacy will have to be very clear from the evidence before a conviction is successful, limited again by the definition of "genocide" itself.

The most controversial aspects of the legislation are those surrounding the new offence of "group defamation". But here, too, the defences, both in the Report and in the legislation as finally enacted, as well as the role of the Attorney General, will make it very difficult for courts ever to have before them frivolous prosecutions or fact situations that really involve serious debate over responsible questions relating to inter-group tensions or political party conflict, no matter how tough or abusive the language used. It has always seemed to the writer very significant that relatively homogenous and socially well-managed societies such as Denmark, the Netherlands, Norway and Sweden (and Switzerland) should have long ago enacted analogous provisions. ${ }^{32}$ In contrast, but perhaps equally important, societies with a much more divisive internal tradition such as France and Italy have also found it desirable to provide for protection against these forms of propaganda. ${ }^{33}$ While in the Commonwealth, Australia and the United Kingdom, have adopted quite stringent legislation, which in the case of the United Kingdom may be said to go farther perhaps than do the presently adopted Canadian amendments."

\section{CONCLUDING REFLECTIONS}

That organizations and individuals with unchallenged credentials in the areas of human rights and general civil liberties should have been so seriously divided on this legislation, as was Parliament itself, undoubtedly suggests that the argument is by no means all one way. But in perspective, the conclusions of the Committee and its recommendations, as well as those of the majority of both Houses of Parliament, reflect authentic anxieties which had to be faced, and faced by law specifically on an issue that could not be dealt with alone by the general educational process one the one hand or by provincial non-discrimina-

\footnotetext{
3: Report, supra, n. 6 at 282 (Denmark), 287 (Netherlands) and 288 (Norway) (Sweden) (Switzerland).

33 Id., at 284 (France) and 285 (Italy).

34 Id., at 277 (Australia) and 98-97 (United Kingdom (as amended)).
} 
tion legislation on the other. Something more was needed if the issue were to be treated seriously. It was argued that the hate propaganda problem had diminished markedly since its peak periods of 1961 to 1966 . That is no answer to the general question of principle or to the practical question of its sporadic reappearance in word and deed, however minimal the volume may be at some moments, thereby leaving a deceptively optimistic impression that the issue was no longer a potentially dangerous one. ${ }^{3 ;}$

The preface to the Report really states the Committee's rationale whether dealing with large or small volumes of propaganda, peak or minimal moments, maximum or minimum sensitivities over a period of time. And this paper well might conclude by relying upon that Preface as the simple justification for the legislation.

\section{PREFACE}

"This Report is a study in the power of words to maim, and what it is that a civilized society can do about it. Not every abuse of human communication can or should be controlled by law or custom. But every society from time to time draws lines at the point where the intolerable and the impermissible coincide. In a free society such as our own, where the privilege of speech can induce ideas that may change the very order itself, there is a bias weighted heavily in favour of the maximum of rhetoric whatever the cost and consequences. But that bias stops this side of injury to the community itself and to individual members or identifiable groups innocently caught in verbal cross-fire that goes beyond legitimate debate.

An effort is made here to re-examine, therefore, the parameters of permissible argument in a world more easily persuaded than before because the means of transmission are so persuasive. But ours is also a world aware of the perils of falsehood disguised as fact and of conspirators eroding the community's integrity through pretending that conspiracies from elsewhere now justify verbal assaults -the non-facts and the non-truths of prejudice and slander.

Hate is as old as man and doubtless as durable. This Report explores what it is that a community can do to lessen some of man's intolerance and to proscribe its gross exploitation."

\section{APPENDIX A}

\section{RECOMMENDATIONS OF SPECIAL COMMITTEE ON HATE PROPAGANDA}

Having in mind, therefore, the detailed evidence set out in Chapter II; the attitudes toward and the consequences of hate propaganda in all of its forms as described and analyzed in Chapters I and III; the deficiencies in the present Canadian law discussed in Chapter IV; and bearing in mind, too, the detailed conclusions expressed in Chapter V; the Committee believes it to be desirable now to draft a proposed series of amendments to the Criminal Code that would express as specifically and clearly as possible, these findings, conclusions and recommendations.

\section{Principal Recommendations}

Our principal recommendations therefore are incorporated in the following proposed draft amendment to the Criminal Code:

(1) Every one who advocates or promotes genocide is guilty of an indictable offence and is liable to imprisonment for five years.

$\therefore$ It is worth asking the interesting. speculative question as to whether a Law Reform Commission beginning to draft a Criminal Code for Canada, de novo, would or would not take into account the contemporary research into social-psychology and related areas, In drafting its provisions for the modern needs of Canada and its values, and its expectations for the future. 
(2) Everyone who, by communicating statements in any public place, incites hatred or contempt against any identifiable group, where such incitement is likely to lead to a breach of the peace, is guilty of

(a) an indictable offence and is liable to imprisonment for two years, or

(b) an offence punishable on summary conviction.

(3) Every one who by communicating statements, wilfully promotes hatred or contempt against any identifiable group is guilty of

(a) an indictable offence and is liable to imprisonment for two years, or

(b) an offence punishable on summary conviction.

(4) No person shall be convicted of an offence under subsection 3

(a) where he proves that the statements communicated were true, or

(b) where he proves that they were relevant to any subject of pubiic interest, the public discussion of which was for the public benefit, and that on reasonable grounds he believed them to be true.

(5) In this section

(a) "Genocide" means any of the following acts committed with intent to destroy in whole or in part, any identifiable group:

(i) killing members of such a group

(ii) deliberately inflicting on such a group conditions of life calculated to bring about its physical destruction.

(iii) deliberately imposing measures intended to prevent births within such a group.

(b) "Public place" includes any place to which the public have access as of right or by invitation, express or implied.

(c) "Identifiable group" means any section of the public distinguished by religion, colour, race, language, ethnic or national origin.

(d) "Statements" include words either spoken or written, gestures, signs or other visible representations.

We have several comments to make on the penalties and definitions in the above draft. In our view the advocacy of genocide is so serious that it requires a more severe sentence than the other offences proposed, and we therefore have recommended that it should be an indictable offence with a sentence of up to five years' imprisonment. As to the other recommended offences we believe that as they would vary considerably in seriousness depending on the circumstances we should provide for the option of prosecution by way of summary conviction or by indictment. Where the prosecution chooses to proceed by way of summary conviction, the accused will be faced with a less serious charge-which balances the fact that he will be deprived, as in the case of all summary conviction offences, of his right to trial by jury. Where, on the other hand, the prosecution chooses to treat the charge as indictable, the accused will retain his right to trial by jury in addition to the other options available to him. We feel that a maximum sentence of two years' imprisonment provides a sufficient upper limit range for most foreseeable situations. 
The Committee also was governed by the desire to depart as little as possible from existing legal concepts and terms, and we therefore adopted the definition of "public place" now in section 130 of the Code. We have also retained the "hatred and contempt" formula traditional to criminal defamation, although we have omitted the 'ridicule" from the phrase for fear of inhibiting legitimate satire and out of a conviction that the kind of "hate" propaganda we are concerned with is much stronger than simple ridicule. The definition of "genocide" is taken (as explained in Chapter IV) from that used in the United Nations Convention on Genocide.

\section{Supplementary Recommendations}

In addition to the above specific recommendations involving legislative changes we also recommend the following as general policy guides in dealing with related aspects of the hate propaganda problem and its control or correction:

a. We recommend that the Minister examine the language of sections 153 and 160 of the Criminal Code in the light of our principal recommendations and our comments on these sections to determine whether they themselves may require amendment.

b. We recommend that the Minister examine the legislation and regulations governing the various Agencies and Departments of the Government of Canada in the light of our comments, particularly those that disclose some significant differences between postal and customs powers-as explained in Chapter IV.

c. We recommend that as far as may be possible, and with due allowance for the particular problems and responsibilities of each Agency and Department, statutes and regulations governing hate propaganda material or activities should be related to the general standard as set out in the Criminal Code rather than to a standard established independently by such agencies and departments, including Broadcasting.

d. We recommend that study be given to the matter of the seizure of hate materials and of their confiscation after conviction.

The Committee considered the advisability of requiring the consent of the Attorney-General of the Province or of Canada to each prosecution instituted under the legislation proposed in order to prevent frivolous or unwarranted prosecutions, and without making any recommendation, we draw the Minister's attention to this possibility.

\section{APPENDIX B}

\section{The House of Commons of Canada BILL C-3}

An Act to amend the Criminal Code

Her Majesty, by and with the advice and consent of the Senate and House of Commons of Canada, enacts as follows:

1. The Criminal Code is amended by adding thereto, immediately after section 267 thereof, the following headings and sections: 


\section{"Hate Propaganda}

267A. (1) Everyone who advocates or promotes genocide is guilty of an indictable offence and is liable to imprisonment for five years.

(2) In this section "genocide" means any of the following acts committed with intent to destroy in whole or in part any identifiable group, namely:

(a) killing members of the group, or

(b) deliberately inflicting on the group conditions of life calculated to bring about its physical destruction.

(3) No proceeding for an offence under this section shall be instituted without the consent of the Attorney General.

(4) In this section "identifiable group" means any section of the public distinguished by colour, race, religion or ethnic origin.

267в. (1) Everyone who, by communicating statements in any public place, incites hatred against any identifiable group where such incitement is likely to lead to a breach of the peace, is guilty of

(a) an indictable offence and is liable to imprisonment for two years; or

(b) an offence punishable on summary conviction.

(2) Everyone who, by communicating statements, other than in private conversation, wilfully promotes hatred against any identifiable group is guilty of

(a) an indictable offence and is liable to imprisonment for two years; or

(b) an offence punishable on summary conviction.

(3) No person shall be convicted of an offence under subsection (2)

(a) if he establishes that the statements communicated were true;

(b) if, in good faith, he expressed or attempted to establish by argument an opinion upon a religious subject;

(c) If the statement were relevant to any subject of public interest, the discussion of which was for the public benefit, and if on reasonable grounds he believed them to be true; or

(d) if, in good faith, he intended to point out, for the purpose of removal, matters producing or tending to produce feelings of hatred towards an identifiable group in Canada.

(4) Where a person is convicted of an offence under section 267A or subsection (1) or (2) of this section, anything by means of or in relation to which the offence was committed, upon such conviction, may, in addition to any other punishment imposed, be ordered by the presiding magistrate or judge to be forfeited to Her Majesty in right of the province in which that person is convicted, for disposal as the Attorney General may direct.

(5) Subsections (6) and (7) of section 171 apply mutatis mutandis to section 267A or subsection (1) or (2) of this section.

(6) No proceeding for an offence under subsection (2) shall be instituted without the consent of the Attorney General.

(7) In this section,

(a) "public place" includes any place to which the public have access as of right or by invitation, express or implied;

(b) "identifiable group" has the same meaning it has in section 267A; and 
(c) "statements" includes words spoken or written or recorded electronically or electromagnetically or otherwise, and gestures, signs or other visible representations; and

(d) "communicating" includes communicating by telephone, broadcasting or other audible or visible means.

267c. (1) A judge who is satisfied by information upon oath that there are reasonable grounds for believing that any publication, copies of which are kept for sale or distribution in premises within the jurisdiction of the court, is hate propaganda, shall issue a warrant under his hand authorizing seizure of the copies.

(2) Within seven days of the issue of the warrant, the judge shall issue a summons to the occupier of the premises requiring him to appear before the court and show cause why the matter seized should not be forfeited to Her Majesty.

(3) The owner and the author of the matter seized and alleged to be hate propaganda may appear and be represented in the proceedings in order to oppose the making of an order for the forfeiture of the said matter.

(4) If the court is satisfied that the publication is hate propaganda, it shall make an order declaring the matter forfeited to Her Majesty in right of the province in which the proceedings take place, for disposal as the Attorney General may direct.

(5) If the court is not satisfied that the publication is hate propaganda, it shall order that the matter be restored to the person from whom it was seized forthwith after the time for final appeal has expired.

(6) An appeal lies from an order made under subsection (4) or (5) by any person who appeared in the proceedings

(a) on any ground of appeal that involves a question of law alone,

(b) on any ground of appeal that involves a question of fact alone, or

(c) on any ground of appeal that involves a question of mixed law and fact,

as if it were an appeal against conviction or against a judgment or verdict of acquittal, as the case may be, on a question of law alone under Part XVIII and sections 581 to 601 apply mutatis mutandis.

(7) No proceedings under this section shall be instituted without the consent of the Attorney General.

(8) In this section,

(a) "court" means a county or district court or, in the Province of Quebec

(i) the court of the sessions of the peace, or

(ii) where an application has been made to a judge of the provincial court for a warrant under subsection (1), that judge;

(b) "genocide" has the same meaning as it has in section 267A;

(c) "hate propaganda" means any writing, sign or visible representation that advocates or promotes genocide or the communication of which by any person would constitute an offence under section $267 \mathrm{~B}$; and

(d) "judge" means a judge of a court or, in the Province of Quebec, a judge of the provincial court." 